What is all that "junk" doing in our genomes?

\title{
“垃圾”DNA 的奥秘
}

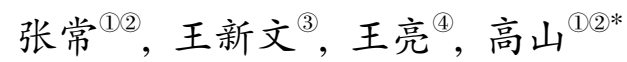

(1) 中国科学院苏州生物医学工程技术研究所, 苏州 215163;

(2) 中国科学院生物医学检验技术重点实验室, 苏州 215163;

(3) 第四军医大学口腔医学院黍膜科, 西安 710032;

(4) 中国科学院微生物研究所病原微生物与免疫学重点实验室, 北京 100101

*联系人, E-mail: gaos@ sibet.ac.cn

2016-03-23 收稿, 2016-05-17 修回, 2016-05-18 接受, 2016-08-19 网络版发表

国家自然科学基金(81472827)、中国科学院“百人计划”和中国科学院重点部署项目(KFZD-SW-204)资助

摘要依据DNA双螺旋和遗传信息的中心法则, 只有编码蛋白的DNA才被认为是有功能的. 然而人类基因组 大小与蛋白质数量矛盾以及生物体进化与基因组大小的不相关性(即 $C$ 值悖论), 导致科学家对非编码DNA概念的 提出，戏称这些DNA为“垃圾”DNA. 随着第二代测序技术发展以及数据分析能力的提升，大量研究表明，这些“垃 圾”DNA很多都可以在生理与疾病状态下特异性转录。同时, 疾病全基因组相关联研究显示, 大量与疾病相关单 核苷酸多态性位点位于非编码区，这共同证明了它们是有功能的。进一步研究表明，人类基因组中至少 $75 \%$ 的序 列是转录的, 并将这些转录且不编码蛋白质的产物称为非编码RNA. 本研究组系统总结了 3 大类非编码RNA包括 微小RNA、长链非编码RNA和环状RNA的定义和分类以及在疾病中的功能, 对这些的非编码RNA的研究将会为疾 病的治疗以及诊断方法开启新纪元.

关键词“垃圾”DNA, 编码 DNA, 非编码 RNA, 长链非编码 RNA, 环状 RNA, 肿瘤

生命的孕育、生长、繁衍和死亡等一切生命现象 是不以人的意志为转移的, 它们皆由基因控制. 早在 1860年, 遗传学家孟德尔通过踠豆(Pisum sativum Linn) 实验提出了遗传定律. 1953年, 詹姆斯. 沃森 (James Waston)和弗朗西斯- 克里克(Francis Crick)发 现并提出了DNA双螺旋结构模型, 标志着分子生物 学时代的开启. 随后, 遗传学“中心法则”的建立、补 充和完善使人们认识了遗传信息是如何传递的. 这 个传递的过程包括核酸之间的双向传递和核酸到蛋 白质的单向传递, 这两种传递方式的结合最终实现 遗传信息在生物体内部以及世代间的传递. 这一过 程的发现暗示, 生命体基因组的绝大部分应该是编 码蛋白质的DNA.

\section{1 “垃圾”DNA的起因}

1964 年, 德国科学家弗里德利希·福格尔 ${ }^{[1]}$ (Friedrich Vogel)在Nature撰文称：若根据当时估算 的人类基因组大小，按照 “中心法则”和基因组都由 蛋白质编码基因组成的原则，那么一个人的基因数 量有可能多达 670 万个, 很显然这个数字大得让人颤 栗，当时对基因组大小认识显示，人类不能够制造出 670 万种蛋白质. 同时, 普遍认为自然界中的生物体 遵循从简单到复杂、从低等到高等进化的模式, 理论 上生物体具有越来越复杂的生命活动，遗传信息也 必然会增加, 那就意味着基因组也会变大, 然而, 事 实却并非如此. 基因组的大小通常用 $C$ 值 $(C$-value)来 表示, 研究发现, $C$ 值与生物体的复杂程度并不呈现

引用格式: 张常, 王新文, 王亮, 等. “垃圾”DNA 的奥秘. 科学通报, 2016, 61: 3079-3084 Zhang C, Wang X W, Wang L, et al. The mystery of “junk” DNA (in Chinese). Chin Sci Bull, 2016, 61: 3079-3084, doi: 10.1360/N972016-00381 
线性关系 ${ }^{[2]}$. 例如, 变形虫 (Amoeba proteus, 一种单 细胞真核生物) 的 $C$ 值大约是人的 $C$ 值 200 倍. 于是, 科学家将这种 $C$ 值和生物的结构或组成的复杂性不 匹配的现象称为“ $C$ 值悖论” $(C \text {-value paradox })^{[3]}$.

虽然当时科学家无法解释这一现象, 但就生命 体中存在非编码DNA这一观点达成共识. 1972年, 日 本遗传学家大野乾 (Susumu Ohno) ${ }^{[4]}$ 提出了 “垃圾” DNA (“junk”DNA)这一概念, 用来描述基因组中不 能编码蛋白质的DNA序列. 这似乎对进化提出挑战, 按常理进化都是 “精准”演化, 用则进, 废则退. 但 “垃圾”DNA的存在, 暗示大自然在基因组演化做得 并不完美, 具有一定的随意性和不确定性. 20 世纪90 年代初期, 由美国科学家发起, 并由英国、法国、德 国、日本和中国科学家相继先后加人, 共同参与实施 了人类基因组计划. 经过科学家不断的努力, 到 21 世 纪初期, 完成了人类基因组“天书”的解读. 结果发 现, 人类的基因总数不超过 $25000^{[5]}$, 在基因组中, 能够编码蛋白的DNA只占到其中的 $1 \%$ 1.5\%, 再除 去 $3 \%$ 左右的调控编码基因的调控元件DNA, 剩余的 95\%以上的DNA序列是没有任何功能的“垃圾”DNA. 显然, 基因组就像在一大片 “垃圾”DNA组成的荒漠 里, 零星地点缀着编码基因及调控元件DNA. 试想 一下, 当人们坐在电影院欣赏一部时长 $100 \mathrm{~min}$ 的电 影, 结果95 min都是在播广告, 仅有的 $5 \mathrm{~min}$ 故事也 被肢解在其中, 人们还会津津有味坐在那里欣赏这 个故事吗? 摆在面前的两大问题: 是真的利用如此 之少的基因构成如此复杂的生命个体? 基因组中“垃 圾”DNA片段真的没有用吗? 显然这两个问题是相互 验证的. 这也好比人类对宇宙的认识, 所认知的宇宙 只占了宇宙的极少一部分, 而大部分是由无法探测 和研究的物质组成, 这部分未知东西被称为 “暗物 质”, 这些未知功能的“垃圾”DNA也被戏称为基因组 中的“暗物质”.

\section{2 “垃圾”DNA的解读}

随着人类基因组计划的完成, 美国国家人类基 因组研究院(National Human Genome Research Institute, NHGRI) 决定对人类基因组进行一番彻底的搜 寻, 看看其中究竟有多少DNA是没有意义、没有功能 的“垃圾”DNA. 得益于测序技术的进步, 第二代测 序技术极大地提高了测序通量, 可以一次性完成从 数十万到数百万的DNA分子测序, 使得对一个物种
的基因组和转录组深度测序变得方便易行，为“垃 圾”DNA的解读提供了技术的支撑. 所以，在2003年 启动的 ENCODE (The Encyclopedia of DNA Elements)计划 ${ }^{[6]}$ 和2006年的癌症基因组计划(The Cancer Genome Atlas, TCGA) ${ }^{[7]}$ 为这些非编码DNA片段的研 究提供了极大的帮助.

众所周知，从统计学意义上来说，人与人之间的 蛋白质编码基因有 $99 \%$ 的相似性，但是，个体的“垃 圾”DNA却有着显著的差异, 这能够较好地解释为何 基因组编码部分大体上相似，每个人却都存在不同. 也就是说, 是“垃圾”DNA让每个人都变得独一无二. 实验发现，在这些“垃圾”DNA中存在大量微小的基 因开关, 控制着基因在细胞中的功能, 构成基因调控 网络里很重要的一环, 这个环节异常, 会导致疾病发 生, 所以这些解读证实人类基因组大部分是有功能 的 $^{[8]}$. 很多过去被认为无功能的DNA, 实际上有可能 转录为 RNA, 或者作为转录因子结合位点, 或者是 DNA化学修饰的靶点, 以多种形式对真正基因的表 达起到了关键的调节作用. 这些研究彻底颠覆了传 统的以蛋白质编码基因为中心的基因组学观念, 并 将人类带人了一个全新的基因组时代, 甚至有科学 家将该计划的一系列研究结果比喻为人类基因组的 Google地图.从下面几个小例子来探讨这些“垃 圾”DNA的重要性.

首先, 不少疾病的全基因组关联研究 (genomewide association study, GWAS)鉴定出许多DNA单核 苷酸多态性(single nucleotide polymorphisms, SNPs) 和这些疾病有一定的关联性，但这些SNPs将近 $90 \%$ 位于传统上所谓的“垃圾”DNA区域里 ${ }^{[9]}$. ENCODE项 目检查了 5000 多个这类SNPs, 发现这些位点在一种 或多种转录因子调节的区域. 而且这些位点还与脱 氧核糖核苷酸酶I(deoxyribonuclease I, DNase I)超敏 位点相关联 ${ }^{[10]}$, 说明这些区域不是传统理解的沉默 区. 这只是ENCODE项目寻求方法以证明不存在所 谓“垃圾”DNA的一个例子. 另外, 有科学家将人和 小鼠(Mus musculus)的基因组序列进行比对, 发现在 非编码DNA中, 有 $5 \%$ 的序列是高度保守的. 选取其 中的一部分序列在大尺度上进行同源分析，发现这 部分序列中超过 $25 \%$ 的部分存在于 10 种以上哺乳动 物的DNA序列中, 保守性甚至比同源的编码蛋白质 基因要强 ${ }^{[11]}$. 这就意味着这些序列经历了几亿年演 变而基本没有发生差异变化. 这种保守性说明它们 
对于物种来说有着非常重要的作用. 同时, 在人类基 因组中, 在基因区和基因之间都包含大量的重复序 列, 其含量占到基因组含量的30\% 50\% ${ }^{[12]}$, 而且重 复序列也与人类疾病的发生密切相关. 例如, 研究人 员通过比对良性和恶性神经鞘瘤的全基因组DNA甲 基化发现重复序列是低甲基化的, 这些重复序列的 异常甲基化与疾病的发生有一定的关联性 ${ }^{[13]}$. 另外, Alu重复序列属于短散布核元件, 在人类基因组中所 占比例大约 $10 \%{ }^{[14]}$. 研究发现, 该序列为新的外显子 的主要来源, 并且是灵长类特异性的反转录转座子, 实验表明, 与肌肉营养失调有关基因 SEPNI (selenoprotein N1), 其中一个外显子来源于 $\mathrm{Alu}^{[15]}$.

更为重要的是, 这些研究证实人类基因组 $75 \%$ 都具有转录活性, 且转录后产物具备一定的生物学 功能 ${ }^{[5]}$. 把这些转录而不编码蛋白的产物统称非编码 RNA (non-coding RNA, ncRNA), ncRNA包括核糖体 RNA (ribosome RNA, rRNA)、转运RNA (transfer RNA, tRNA)、小核RNA (small nuclear, snRNA)、核 仁小分子RNA (small nucleolar RNA, snoRNA)、微小 RNA (micro RNA, miRNA)、长链非编码RNA (long non-coding RNA, IncRNA)、环状RNA (circular RNA, circRNA) 等. 当前, ncRNA的研究热点主要聚焦在这 几大类, 一类就是研究比较清楚的 miRNA, 一类是 刚被重视起来的lncRNA, 还有一类就是新崛起的 circRNA.

\section{1 miRNA}

miRNA 是一种内源性的小 RNA, 成熟的 miRNA 大小长约20 25 bp, 不具备编码蛋白质的能力, 但是 能够调控编码基因的表达. 这些成熟的 miRNA是由 初级转录产物经过一系列核酸酶的剪切加工而成的, 随后组装进 RNA诱导的沉默复合体 (RNA-induced silencing complex, RISC), 通过碱基互补配对的原则 识别靶 mRNA 的 $5^{\prime}$ 或 $3^{\prime}$ 非翻译区域, 从而引起靶 mRNA降解或抑制其翻译活性 ${ }^{[16]}$.

miRNA广泛存在于生物体内, 在序列结构上具 有高度的保守性, 但表达方式具有时空和组织特异 性. 1993年, 科学家从秀丽隐杆线虫 (Caenorhabditis elegans)体内鉴定出第一个miRNA: lin-4, 证明其通 过反式作用调控编码基因lin-14的活性, 从而影响线 虫的发育 ${ }^{[17]}$. 随后, 越来越多的miRNA被发现, 并 被证实参与各种生物学进程. 例如, 细胞生长、发育、
调亡、代谢、激素信号及分化等。进而人们发现, miRNA的表达水平与多种癌症相关, 该方向目前已 成为肿瘤研究领域的热点. 研究表明, miRNA基因主 要位于染色体的脆性位点上, 而染色体中的脆性位 点区域更易引发癌症的滋生 ${ }^{[18]}$. 大部分的miRNA在 行使其生物学功能时扮演着抑癌基因或类似癌基因 的角色. 例如, Let-7在多种肿瘤中被证实也具有抑癌 基因的作用, 可以抑制癌基因 $R A S$ (rat sarcoma virus) ${ }^{[19]}, M Y C$ (v-myc avian myelocytomatosis viral oncogene homolog) ${ }^{[20]}$, HMGA2 (high mobility group A2) ${ }^{[21]}$ 等的活性. MiR-21作为一种类似癌基因的 $\operatorname{miRNA}^{[22]}$, 在多种癌症中过度表达以维持肿瘤的生 长, 还可以靶向一些肿瘤抑制基因和人侵基因, 在增 加肿瘤的增殖和迁移能力方面发挥重要作用.

\subsection{IncRNA}

$\operatorname{lncRNA}$ 通常是指长度大于 200 个核苷酸的一类 非编码RNA. 基于lncRNA在与邻近其基因的相对位 置和转录方向, 可以将其分为 5 类: 正义 $\operatorname{lncRNA}$ 、反 义 $\operatorname{lncRNA}$ 、内含子lncRNA、基因间lncRNA、双向 lncRNA. IncRNA与 miRNA前体一样, 都具有细胞和 组织特异性, 能够形成二级结构, 并且转录后需要经 过加工和修饰等特点. 和mRNA相比, IncRNA的表达 水平相对较低, 而且在物种间的保守性较差. IncRNA 已被证实在生物体内主要通过对表观遗传、转录调控 及转录后加工等环节的干预发挥功能, 在各种疾病 发病过程中发挥重要作用. 例如, 在癌症中, IncRNA 的异常表达影响癌细胞的增殖、调亡和侵人等. 同时, IncRNA的功能与表达的丰度存在很大关联, 这有可 能使其成为一种癌症诊断和预后评估的理想标志 物 ${ }^{[23]}$.

目前, 有几个 lncRNA已经被选为人类癌症检测 的生物标志物. 其中新型前列腺抗原3 (prostate cancer antigen 3, PCA3) 作为诊断前列腺癌的生物标志物 已获美国食品药品监督管理局(Food and Drug Administration, FDA)批准. 尤其把传统的前列腺特异抗 原(prostate-specific antigen, PSA)和PCA3检测结合起 来, 展示了更高的准确率 ${ }^{[24]}$. 另外, HOX转录反义 RNA(HOTAIR) 是一个位于HOX基因家族反义链的 $\operatorname{lncRNA}{ }^{[25]}$. 研究表明, HOTAIR 在肺癌、结直肠癌、 乳腺癌等多种常见癌症的引发和恶化中起重要作用, 在癌组织中表达量均出现不同程度的异常. HOTAIR 
通过对组蛋白进行表观遗传的修饰, 从而导致了 WIF-1 (wnt inhibitor factor 1), PTEN (phosphatase and tensin homolog deleted on chromosome ten)等基因的 表达调控异常, 影响了WNT (wingless int1), AKT (protein kinase B) 等信号通路, 进而使肿瘤细胞获得 侵袭转移、逃避生长抑制、抵抗细胞凋亡等特性. 因 此, HOTAIR可作为一种分子标记或靶点, 在恶性肿 瘤的早期诊断、疗效判断、预后预测等方面具有广阔 的临床应用前景.

另外, 研究还发现, 在预测的 IncRNA序列内部 发现了具有编码能力的微肽. 例如, 道格拉斯. 安德 森(Douglas Anderson)和本杰明.尼尔森(Benjamin Nelson)等人先后发现了两个在骨骼肌特异表达的 IncRNA序列中, 分别包含一段可以编码 46 个氨基酸 的微肽 myoregulin ${ }^{[26]}$ 和 34 个氨基酸的肽 dwarf open reading frame(DWORF) ${ }^{[27]}$, 它们对骨骼肌的生理具 有重要的调控作用.

\section{3 circRNA}

circRNA是一种内源性的、非线性的非编码RNA, 与传统的线性RNA不同, circRNA由反向剪接产生, 具有封闭的环状结构, 能够抑制核酸外切酶或RNase R 的降解, 并且缺乏 $5^{\prime}$ 端的帽子结构和 $3^{\prime}$ 端的 poly(A) 尾. circRNA主要来自编码基因的外显子, 可能仅有
一个外显子构成, 也可能由多个外显子构成. circRNA在组织中广泛表达, 具有发育阶段特异性和物种 的保守性.

早在 19 世纪 80 年代, circRNA就被科学家所发 现 $^{[28]}$, 但是由于中心法则的盛行, 不具备编码能力 的环状RNA在当时根本不受重视. 进人 21 世纪, 得 益于非编码RNA研究的兴起和深度测序技术以及生 物信息学的快速发展, 才使得 circRNA渐渐浮出水面. 目前发现，一些circRNA在细胞质中可充当miRNA海 绵分子 ${ }^{[29]}$. 例如, ciRS-7主要在脑中尤其是小脑中大 量表达, 它包含超过70个 miR-7的结合位点, 通过结 合 miR-7抑制其活性, 从而影响 miR-7靶基因的活性, 而miR-7又直接或间接调控癌症相关的信号通路中致 癌相关蛋白活性 ${ }^{[30]}$. circRNA还可作为RNA结合蛋白 (RNA binding protein, RBP)的隔绝子, 或核内翻译的 调控子, 是基因表达调控网络的重要参与者 ${ }^{[31]}$.

伊萨克·牛顿早就说过, “自然不行徒劳之举, 少 已够用, 多则何益”. 非编码RNA既然随着物种的进 化并没有消失，肯定是“天生我才必有用”。而且现在 越来越多的科学研究已经证明了各类非编码RNA存 在的生理意义及重要的应用价值. 随着科学技术的 不断进步、发展和科学家坚持不解的努力, 我们期待 真正理解、掌握并最终运用生命这部“天书”, 为人类 生命科学研究作贡献.

\section{参考文献}

1 Vogel F. A preliminary estimate of the number of human genes. Nature, 1964, 201: 847

2 Thomas C A Jr. The genetic organization of chromosomes. Annu Rev Genet, 1971, 5: 237-256

3 Eddy S R. The C-value paradox, junk DNA and ENCODE. Curr Biol, 2012, 22: R898-R 899

4 Ohno S. So much “junk” DNA in our genome. Brookhaven Symp Biol, 1972, 23: 366-370

5 Djebali S, Davis C A, Merkel A, et al. Landscape of transcription in human cells. Nature, 2012, 489: 101-108

6 ENCODE Project Consortium. The ENCODE (ENCyclopedia of DNA elements) project. Science, 2004, 306: 636-640

7 Cancer Genome Atlas Research Network, Weinstein J N, Collisson E A, et al. The Cancer Genome Atlas Pan-Cancer Analysis Project. Nat Genet, 2013, 45: 1113-1120

8 ENCODE Project Consortium. An integrated encyclopedia of DNA elements in the human genome. Nature, 2012, 489: 57-74

9 Schaub M A, Boyle A P, Kundaje A, et al. Linking disease associations with regulatory information in the human genome. Genome Res, 2012, 22: 1748-1759

10 Thurman R E, Rynes E, Humbert R, et al. The accessible chromatin landscape of the human genome. Nature, 2012, 489: 75-82

11 Dermitzakis E T, Reymond A, Scamuffa N, et al. Evolutionary discrimination of mammalian conserved non-genic sequences (CNGs). Science, 2003, 302: 1033-1035

12 Faulkner G J, Kimura Y, Daub C O, et al. The regulated retrotransposon transcriptome of mammalian cells. Nat Genet, 2009, 41: 563-571

13 Feber A, Wilson G A, Zhang L, et al. Comparative methylome analysis of benign and malignant peripheral nerve sheath tumors. Genome Res, 2011, 21: 515-524

14 Schmid C W. Alu: A parasite's parasite? Nat Genet, 2003, 35: 15-16 
15 Lin L, Shen S, Tye A, et al. Diverse splicing patterns of exonized Alu elements in human tissues. PLoS Genet, 2008, 4: e1000225

16 Bartel D P. MicroRNAs: Genomics, biogenesis, mechanism, and function. Cell, 2004, 116: 281-297

17 Lee R C, Feinbaum R L, Ambros V. The C. elegans heterochronic gene lin-4 encodes small RNAs with antisense complementarity to lin-14. Cell, 1993, 75: 843-854

18 Calin G A, Sevignani C, Dumitru C D, et al. Human microRNA genes are frequently located at fragile sites and genomic regions involved in cancers. Proc Natl Acad Sci USA, 2004, 101: 2999-3004

19 Johnson S M, Grosshans H, Shingara J, et al. RAS is regulated by the let-7 microRNA family. Cell, 2005, 120: 635-647

20 Sampson V B, Rong N H, Han J, et al. MicroRNA let-7a down-regulates MYC and reverts MYC-induced growth in Burkitt lymphoma cells. Cancer Res, 2007, 67: 9762-9770

21 Park S M, Shell S, Radjabi A R, et al. Let-7 prevents early cancer progression by suppressing expression of the embryonic gene HMGA2. Cell Cycle, 2007, 6: 2585-2590

22 Si M L, Zhu S, Wu H, et al. MiR-21-mediated tumor growth. Oncogene, 2007, 26: 2799-2803

23 Yarmishyn A A, Kurochkin I V. Long non-coding RNAs: A potential novel class of cancer biomarkers. Front Genet, 2015, 6: 145

24 Bussemakers M J, van Bokhoven A, Verhaegh G W, et al. Dd3: A new prostate-specific gene, highly overexpressed in prostate cancer. Cancer Res, 1999, 59: 5975-5979

25 Hajjari M, Salavaty A. HOTAIR: An oncogenic long non-coding RNA in different cancers. Cancer Biol Med, 2015, 12: 1-9

26 Anderson D M, Anderson K M, Chang C L, et al. A micropeptide encoded by a putative long noncoding RNA regulates muscle performance. Cell, 2015, 160: 595-606

27 Nelson B R, Makarewich C A, Anderson D M, et al. A peptide encoded by a transcript annotated as long noncoding RNA enhances SERCA activity in muscle. Science, 2016, 351: 271-275

28 Sanger H L, Klotz G, Riesner D, et al. Viroids are single-stranded covalently closed circular RNA molecules existing as highly base-paired rod-like structures. Proc Natl Acad Sci USA, 1976, 73: 3852-3856

29 Hansen T B, Jensen T I, Clausen B H, et al. Natural RNA circles function as efficient microRNA sponges. Nature, 2013, 495: 384-388

30 Lasda E, Parker R. Circular RNAs: Diversity of form and function. RNA, 2014, 20: 1829-1842

31 Memczak S, Jens M, Elefsinioti A, et al. Circular RNAs are a large class of animal RNAs with regulatory potency. Nature, 2013, 495: $333-338$

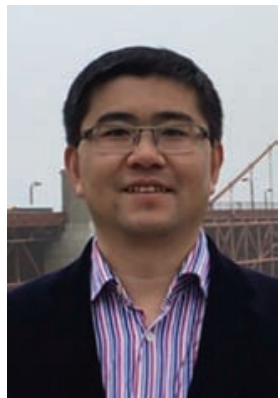

\section{高山}

牛津大学医学肿瘤学博士, 中国科学院苏州生物医学工程技术研究所研究员, 博士生导师。中国科学院“百人计划”获得者和江苏省“六大人才高峰”入选者. 现任中国科学院生物医学检验技术重点实验室副主任和生物标志物研究中 心主任. 长期从事肿瘤的分子机制和生物标志物的研究, 以及新型生物技术 研发, 注重基础医学与转化医学相结合, 逐渐在这些领域形成了具有特色和 影响力的系统性研究体系. 


\title{
The mystery of “junk" DNA
}

\author{
ZHANG Chang ${ }^{1,2}$, WANG XinWen ${ }^{3}$, WANG Liang $^{4}$ \& GAO Shan ${ }^{1,2}$ \\ ${ }^{1}$ Suzhou Institute of Biomedical Engineering and Technology, Chinese Academy of Sciences, Suzhou 215163, China; \\ ${ }^{2}$ Key Laboratory of Bio-medical Diagnostics, Chinese Academy of Sciences, Suzhou 215163, China; \\ ${ }^{3}$ Department of Oral Medicine, School of Stomatology, The Fourth Military Medical University, Xi'an 710032, China; \\ ${ }^{4}$ CAS Key Laboratory of Pathogenic Microbiology and Immunology, Institute of Microbiology, Chinese Academy of Sciences, Beijing 100101, China
}

The basic genetic law of life is built based on DNA double helix model and the central dogma of molecular biology (i.e. DNA-RNA bidirectional transcription and RNA-protein translation), in which DNA and most of RNA carry coding information, and proteins make up the structure of the body and carry out most of biological functions. This describes the flow of genetic information within and between individual and protein as the functional molecules in life, so DNA that codes for protein (known as exon) is functional in view of these rules. In this review, we provide an overview of the origin of "junk" DNA and further discuss how "junk" DNA functions in depth. With a glimpse on landscape of human genome, only very small fractions are protein coding DNA in our book of life. By contrast, the large fractions are non-coding DNA, which cannot be translated into proteins and have been assumed that such DNA do not contain any information nor have function. Also it has been found that the genome size of organism does not correlate well with the complexity of organism, suggesting large amounts of non-coding DNA exist in lower organism. Such non-coding DNA in organism genome are regarded as uselessness and commonly referred to as "junk" DNA. However, with the advent of next generation sequencing technologies and ability to improvement of analyzing data, these provide the possibility to systematically understand so called "junk" DNA. First, genome-wide association studies have successfully identified many single nucleotide polymorphisms (SNPs) underlying susceptibility to diseases; however, the majority of SNPs locate in non-coding region of genome. Moreover, the parts of non-coding DNA are highly conserved between human and mice. All of these suggest non-coding DNA are functional in some way. Second, it has been revealed that about 75 percent of our genome is actually transcribed. Such transcripts that do not code any protein are termed as non-coding RNAs (ncRNAs). These ncRNAs, such as canonical transfer and ribosomal RNAs, as well as the recently identified microRNAs (miRNAs), long non-coding RNAs (lncRNAs) circular RNAs (circRNAs) etc, have been shown to play the important physiological function in organism. Also the deregulation of these ncRNAs has been found to have relevance not only to tumorigenesis, but also to neurological, cardiovascular, developmental and other diseases. Here we further discuss the rapidly advancing fields of miRNA, IncRNA and circRNA in detail. We summarize their production, gene structure and organization in the genome and diverse functions. Although miRNA has been well studied in last decade, we are still in early step of understanding the nature and extent of the involvement of other ncRNAs in physiology and disease. This will shed light on great advances in therapeutic strategies and diagnostic approaches based on the understanding on the molecular mechanisms of ncRNAs.

\section{“junk” DNA, coding DNA, non-coding RNA, long non-coding RNA, circular RNA, tumor}

doi: $10.1360 /$ N972016-00381 